PARtake: The Journal of Performance as Research Volume 3, Issue 1 - Spring 2020 ISSN: $2472-0860$

Revisiting the Rusty Ring: Ecofeminism Today?

Annette Arlander, MA, DA-University of the Arts Helsinki 
(The following text is a transcript of the voice-over text, the spoken and recorded text added to the video.)

The video you see is a revisit, on 20th December 2018, to the site where Year of the Ox - Walking in Circles and Day and Night of the Ox were performed in 2009. The rusty ring was there on the cliffs as before, but I could not find the rusty chain I used to attach to it and used a simple rope instead. As part of the research project "How To Do Things With Performance" I have revisited old works, especially a twelve-year project based on weekly performances for [the] camera on Harakka Island in Helsinki, and the resulting series of video works called Animal Years, made between 2002 and 2014. Some of these revisits have resulted in video essays, such as "The Shore Revisited" (2018) or "Return to the Site of the Year of the Rooster" (2019). Now the turn has come to [the] year of the ox. This video essay consists of two of the old works from that year inserted into the recording of the recent revisit to the site. I will use this compilation as an impulse to revisit some ecofeminist ideas about our relationship to nature, environment and place and as a backdrop of sorts.

The synopsis for the video work depicting one year reads: "A rust-colored scarf around my shoulders, I walk in a circle tied with a chain to an iron ring on a cliff on the South-Eastern shore of Helsinki's Harakka Island once a week for a year, between 25 th January 2009 and 6th February 2010." While the synopsis for the day and night, which you will see soon, reads as follows: "With a rust-colored scarf around my shoulders, I walk in a circle tied with a chain to an iron ring on a cliff on the South-Eastern shore of Helsinki's Harakka Island every two hours during a day and night between 1 st May 2009 at 6 pm and 2nd May at 6pm.”

I have discussed these works, as well as other works made during the same year, wearing the same scarf, such as Year of the Ox-Riding a Buoy or Year of the OxSitting in a Wall, in a text called "Performing Time Through Place," published in 2012 and available online. There I focus on Doreen Massey's ideas of a place as a meeting place and combine the planetary time of one year or one day and night with the historical layers of Swedish, Russian, and Finnish military rule still visible in the buildings and constructions on the island.

What brought me to ecofeminism was the reaction of a colleague to what she saw as a provocative confrontation between the nesting seagulls and the human 
performer. That seems like the very opposite of an ecofeminist sensibility, at least understood in a superficial sense.

So, let's begin by listening to the birds. (pause)

At this point, I should explain that despite my interest in landscape, and despite belonging roughly to the same generation with the founders of ecofeminism, ecofeminism has remained rather unfamiliar to me. In my mind, ecofeminism has been related to Goddess mythologies, motherhood, natural living, biodynamic agriculture, crafts, and so on, all admirable endeavors but not so easy to accommodate with the urban, postmodern, and cyborg sensibilities I was surrounded by in the 1980s. The idea of "mother earth" or "mother nature" and the assumption that women would have a natural affinity with nature through motherhood has later been severely and rightly criticized. Today, however, ecofeminism is re-appearing in new forms in many activist contexts. At the time of the climate crisis, mass extinction of species, explosion of toxic waste in oceans, and indigenous struggles for land rights, the idea that degradation of nature and the environment is linked to the degradation of women's' rights seems important again. Today it seems ever more necessary to overcome the strange aversion with regard to nature, or the environment, which prevails among many of those who feel policed by ideas of "the natural," because it is so often used to justify binary gender roles and racialized structures of exploitation and oppression.

The closest I have come to issues related to ecofeminism recently is via Stacy Alaimo. In her book, Bodily Natures - Science, Environment, and the Material Self (2010), Alaimo introduces the concept trans-corporeality to describe human corporeality, in order to underline how the human is always intermeshed with the morethan-human world and ultimately inseparable from 'the environment.' In "early twentyfirst century realities," she writes, “'human' and 'environment' can by no means be considered as separate." 1 She focuses on issues of environmental justice and environmental health and gives an account and critique of previous feminist theorizations of the body. For her, "trans-corporeality as a theoretical site is where corporeal theories, environmental theories and science studies meet and mingle."2 In any case, "the material self cannot be disentangled from networks that are simultaneously economic, political, cultural, scientific, and substantial,"3 she notes. Alaimo emphasizes "the need to cultivate a tangible sense of connection to the material 
world" to counter "the pervasive sense of disconnection that casts "environmental issues' as containable, eccentric, dismissible topics."4 This dismissal is no longer so easy today, with the increasing awareness of the climate crises, the extinction of species, and disasters, which are no longer concerns for specialists only.

Before continuing further, let's hear what the birds had to say on that day in the beginning of May. (pause)

What has ecofeminism to do with these videos of a human figure walking in circles on the cliffs tied with a chain to a rusty ring? There is no nurturing or caring intended, but rather a drudgery of sorts, even a violence, through the act of whipping the heavy metal chain over the ring to keep it mobile. By being literally chained to the spot, am I trying to stress our dependence of the ground we tread on? Or is it a selfironic comment to the repetitive way of working, which by then I was tiring of? Or is it a play with associations to the toil of the animal of that year, the year of ox? Am I trying out the position of the ox?

When making these works, I had no thoughts of ecofeminism. When looking at the videos now, I realize they could be discussed in terms of 'motherhood.' The nesting birds and especially the seagulls who love to create drama are making a big fuss of my repeated circling on their territory in springtime, especially in the Day and Night of the $O x$, recorded on the first of May 2009. While performing, I took it as a challenge, an ordeal, and was rather scared at times because a seagull couple made their nest almost exactly in the spot where I had placed my tripod. Later I learned that I could have prevented that by putting some branches and twigs there well in advance of the nesting season. I saw the eggs turn into small fluffy chicks and survive my repeated visits. Thus, for me, the violent reactions of the seagulls and other birds were their rightful but exaggerated way of protesting, which I chose to ignore. We were fighting for the right to use those cliffs, and I was convinced that they should get used to me, as I tried to get used to them.

When I showed the video as part of a compilation, a colleague reacted very strongly and was horrified at the suffering she felt I caused to the birds, or perhaps at what she saw as an uneven combat. That reaction opened my eyes for a different reading of the situation than the one I had experienced. As a woman and potential mother, I should, in simple ecofeminist terms, have another sensibility to empathize with the nesting birds. Well, I did not. I thought the birds were deliberately overreacting and 
trying to chase me away, and had the right to do that, of course. But I had also the right to resist. From today's perspective, I can see the ethical problems in my attitude, but I find the example nevertheless interesting in terms of ecofeminist ideas. What is our relationship to nature and to other beings as part of it? Do we idealize nature as something alien to be protected from humans? Or do we see ourselves as part of nature and its processes, enmeshed and entwined with its various life forms?

\section{What is Ecofeminism?}

The first site I encountered in response to my search with that question, called "Women and Life on Earth" (no date), explains: "Ecofeminism is an activist and academic movement that sees critical connections between the domination of nature and the exploitation of women." 5 Moreover, "[e]cofeminist activism grew during the 1980s and 1990s among women from the anti-nuclear, environmental, and lesbianfeminist movements." 6 The site mentions the conference "Women and Life on Earth: Ecofeminism in the Eighties" held at Amherst in 1980 as "the first in a series of ecofeminist conferences, inspiring the growth of ecofeminist organizations and actions..."7 This was all news to me.

A website called "Ecofeminism for beginners" (2018) notes that “'[e]cofeminism' (or environmental feminism) might seem like a new-fangled term thrown around by millennials, but this socio-political theory, which connects both environmental and gender issues to the structure of patriarchy, has actually been around since the 1970s as an offshoot of the environmental activism of that period." 8 We further learn that the "term was first used by French feminist and activist Françoise d'Eaubonne in her 1974 book Le Féminisme ou la Mort, in which she relates the oppression of 'subordinate groups' (such as women and people of colour) to the oppression of nature by man."9 The fact that many environmental activists in the 1970s were women, led to ideas "that the split between nature and society could be healed only by women's 'nurturing spirit"," or the ideas of the importance of "certain 'feminine' values present in nature - such as reciprocity, co-operation, and nurturing." 10 Such emphasis on gender binaries seems slightly odd today, although there is also a widespread interest in the ethics of care.11

Another useful summary is included in "A Very Short Summary of Ecofeminism Theory and Practice" (2012). There we can read that although "ecofeminism is a broad category referring to a plurality of theoretical positions /.../ 
most ecofeminists would agree on several core assumptions" such as the "significant connections between the oppression of women and the oppression of nature," the "need to understand linkages between the oppressions of women and nature in order to understand the oppression of women and the oppression of nature" and the double demand that "[f]eminist theory and practice must consider ecological/environmental perspectives" while "[e]cology and environmental ethics must include feminist perspectives." 12

With these basic introductions in mind, we can try to understand some more specific debates. For example, an article titled "Ecofeminism and Globalism" (2001) published in Democracy and Nature, argues for a material ecofeminism. While ecofeminism sees "the domination of women and nature" as "intrinsically linked," material ecofeminists "focus on the material conditions of women's lives locating the source of this twin domination in patriarchal capitalism." 13 The writers point out that "this materialist emphasis is not common to all ecofeminist thinkers." Some "spiritually oriented ecofeminists seek to celebrate women and their association with nature as a source of strength, power and virtue." 14 This is seen as problematic by material ecofeminists, who are "critical of the tendency of spiritual ecofeminists to endorse essentialism, that is the view that men and women are essentially and inherently different in character and nature." 15 Moreover, a materialist ecofeminist analysis, "sees spiritual ecofeminism as failing to come to terms with the effects of capitalism, such as the perpetuation of sexism and environmental damage."16

\section{Ecofeminism and New Materialism?}

Fifteen years later, in her article "Ecofeminist Echoes in New Materialism?" (2016) Marie-Anne Casselot argues that bringing ecofeminism and new materialism together would be fruitful "because ecofeminism can offer illuminating insights to new materialism especially when it comes to analyzing oppression and the effects of oppressive structures on humans, 'natural others' and more-than-human elements." 17 She maintains that "[n]ew materialism would benefit from a close rereading of ecofeminist theory and history" while new materialism "could extend ecofeminist insights beyond a closed worldview of the natural world by infusing its dynamic new theorizations of the fluidity and the indeterminacy of matter." 18 According to her " $[t]$ he political and ethical strength of ecofeminism could be enhanced by new materialist 
ontological claims because it makes clear the connection between corporeality and environment, while avoiding positing a gendered special connection to nature."19

In her concluding remarks, Casselot notes that "ecofeminism and new materialism share some objects of study but they do not approach them in the same manner." 20 They share an "opposition to dualism and dichotomies," "a special interest in embodiment," and the "goal of positing new ethical practices and new political understandings of the world." 21 For instance, "ecofeminism and new materialism differ on agency /--/ Who is the ecological subject? Can there be a "subject" if we grant agency to inert matter and natural elements?"22 Lastly, they differ in terms of constructivism-essentialism: "while ecofeminism has been somewhat split between its essentialist and constructivist trends, new materialism more boldly goes beyond both constructivism and essentialism." 23

Casselot notes that, on the one hand, "ecofeminism has been criticized for cultural appropriation of Indigenous and Native spiritualities, for being Western-centric and color-blind." 24 On the other hand, today, "ecofeminist activism is interconnected more than ever before with struggles against speciesm, racism, [and] colonialism." 25 She strongly believes "there are inspiring coalitions to construct, theoretically and politically, between ecofeminists and new materialists." 26

\section{Decolonizing Relationships with Nature}

Inspired by these claims, I started looking for ecofeminist classics and encountered Val Plumwood. In one of her latest texts, "Decolonizing relationships with nature" (2003), Plumwood provides a clarifying account of some of the mechanisms that characterize both colonial and anthropocentric approaches to the other, namely a strong focus on dualism, exaggerating differences and denying commonality. One aspect is hyper-separation or radical exclusion: "The function of hyper-separation is to mark out the Other for separate and inferior treatment." 27 In looking at the environment "from an anthropocentric standpoint, nature is a hyper-separate lower order, lacking any real continuity with the human." 28 Moreover, such a perspective "stresses heavily those features that make humans different from nature and animals, rather than those we share with them." 29 Another mechanism is homogenization or stereotyping, seeing the Other "not [as] an individual, but a member of a class stereotyped as interchangeable, replaceable, all alike - that is, as homogenous." 30 Moreover, "[a]ntropocentric culture conceives of nature and animals as all alike in their lack of 
consciousness, which is assumed to be exclusive to the human." 31 Plumwood summarizes: "These two features of human/nature dualism - radical exclusion and homogenization - work together to produce, in anthropocentric culture," she adds, "a polarized understanding in which the human and non-human spheres correspond to two quite different substances or orders of being in the world." 32

And this makes sense for my relationship to the nesting birds I was competing with on the island. On the one hand, I did not see them as totally other, but rather as complaining or irritating neighbors to quarrel with. On the other hand, I was homogenizing them into a pack, despite the very different reactions of, for example, seagulls and geese. Regardless of this specific case, watching out for these two mechanisms, radical exclusion, and homogenization, which easily creep into discussions concerning the environments we share with other life forms, could be a way to rethink our way of cohabiting. And also, a way to begin to acknowledge the work done by early ecofeminists like Plumwood, today.

When looking at the old videos inserted in my recent revisit to the site, I cannot help sighing at the naïveté in my attempts at performing landscape. But I also recognize my striving to articulate a bonding to place, situatedness, and dependence as facts of life, rather than something to idealize, to like or dislike. My relationship to the environment in these works is not to an imagined wilderness, but to place as a meeting place, as suggested by Massey, to nature as our crowded home, where we have to learn to negotiate our living with others, be they seagulls, geese, microbes or other humans. And to do it more wisely and sensitively than I was doing at the time.

1 Stacy Alaimo, Bodily Natures: Science, Environment, and the Material Self,

(Bloomington \& Indianapolis, Indiana University Press, 2010), 2.

2 Ibid., 3.

3 Ibid., 20.

4 Ibid., 16.

5 "What is ecofeminism?" Women and Life on Earth, January 2018, http://www.wloe.org/what-is-ecofeminism.76.0.html

6 Ibid.

7 Lois Ann Lorentzen and Heather Eaton 2002 as quoted in "What is ecofeminism?" 8 Rutvi Zamre and Rea Kamath, "Ecofeminism for beginners," Rebootmag June 4, 9 Ibid. 2018. https://rebootmag.com/2018/06/04/ecofeminism-for-beginners/ n.p. 10 Ibid. 
11 For example the theme of the PSi (performance studies international) conference 2020 is the crises of care http://psi2020rijeka.com/

12 Hollace Graff and Marian Staats, "A Very Short Summary of Ecofeminism Theory and Practice," (Oakton Community College, 2012), https://www.oakton.edu/user/2/hgraff/WGSSummaryEcofeminism.html

13 Jasmin Sydee and Sharon Beder, "Ecofeminism and Globalism: Abstract,"

Democracy and Nature: The International Journal of Inclusive Democracy 7, no. 2 (2001), https://www.democracynature.org/vol7/beder_sydee_globalisation.htm 14 Ibid.

15 Ibid.

16 Ibid.

17 Marie-Anne Casselot "Ecofeminist Echoes in New Materialism?" PhaenEx 11, no.1 (2016), 73-96.

18 Ibid., 73.

19 Ibid., 73.

20 Ibid., 73.

21 Ibid., 92.

22 Ibid., 92.

23 Ibid., 92.

24 Ibid., 93.

25 Ibid., 93.

26 Ibid., 93.

27 Val Plumwood, "Decolonizing relationships with nature," in William M. Adams and Martin Mulligan (eds.) Decolonizing Nature. Strategies for Conservation in a Post-colonial Era, (London and Sterling, VA, Earthscan Publications Ltd., 2003), 54.

28 Ibid., 54.

29 Ibid., 54.

30 Ibid., 55.

31 Ibid., 55.

32 Ibid., 55. 